\title{
Regulatory T cells mediated immunomodulation during asthma: a therapeutic standpoint
}

\author{
Mohammad Afzal Khan*
}

\begin{abstract}
Asthma is an inflammatory disease of the lung airway network, which is initiated and perpetuated by allergen-specific $\mathrm{CD}^{+} \mathrm{T}$ cells, IgE antibodies, and a massive release of Th2 cytokines. The most common clinical manifestations of asthma progression include airway inflammation, pathological airway tissue and microvascular remodeling, which leads to airway hyperresponsiveness (AHR), and reversible airway obstruction. In addition to inflammatory cells, a tiny population of Regulatory T cells (Tregs) control immune homeostasis, suppress allergic responses, and participate in the resolution of inflammation-associated tissue injuries. Preclinical and clinical studies have demonstrated a tremendous therapeutic potential of Tregs in allergic airway disease, which plays a crucial role in immunosuppression, and rejuvenation of inflamed airways. These findings supported to harness the immunotherapeutic potential of Tregs to suppress airway inflammation and airway microvascular reestablishment during the progression of the asthma disease. This review addresses the therapeutic impact of Tregs and how Treg mediated immunomodulation plays a vital role in subduing the development of airway inflammation, and associated airway remodeling during the onset of disease.
\end{abstract}

Keywords: Inflammatory cells, Airway inflammation, Regulatory T cells, Immunosuppression

\section{Background}

Asthma is an inflammatory disease of the lungs, which leads to wheezing and exacerbates breathing in the affected patients, and globally more than 339 million people are suffering, and more than $80 \%$ of asthmaassociated fatalities occur in low-income countries and therefore new therapeutics are warranted to subdue and control asthma [1-8]. Pathologically, the progression of asthma is defined by airway epithelium hyperplasia, mucus cell metaplasia, increased airway smooth muscle mass, and increased deposition of extracellular matrix proteins, which disarray normal functioning of the lung airway system [9]. Airway inflammation is mediated by $\mathrm{T}$ cells, $\mathrm{B}$ cells, macrophages, eosinophils, and

*Correspondence: mkhan26@kfshrc.edu.sa

Organ Transplant Research Section, Comparative Medicine Department,

King Faisal Specialist Hospital and Research Centre, Riyadh, Saudi Arabia activated complement fragments, which play a critical role in tissue injury, and remodeling [6,10-14]. Airway tissue associated remodeling phase refers to structural perturbations during asthmatic airway inflammation, and these perturbations are initiated and regulated through a series of cellular and molecular responses [15-20]. The conventional therapeutic formulations to control asthma have focused on the use of potent antiinflammatory drugs, particularly steroids, which have broad-spectrum suppressive activity against effector cells and their mediators [21]. Management and control of asthma include inhaled corticosteroids, bronchodilators $(\beta$-agonists and anticholinergics), theophylline, leukotriene-receptor antagonists, leukotriene synthesis inhibitors, anti-IgE antibodies, anti-IL5 antibodies, and anti-IL4/IL13 antibodies [22-25]. Although, most popular glucocorticoid regimens are potent in most asthma patients but ineffective to support continuous 
respite of disease without repeated long-term administration, which can be associated with serious toxic sideeffects, and fail to control the disease in a large number of asthma patients [26].

\section{Airway inflammation}

Airway inflammation during asthma is characterized by the accumulation of Th2 type cells, IgE, and eosinophils, which leads to airway hyperresponsiveness and tissue remodeling. As a result, this inflammatory condition is related to a defective $\mathrm{T}$ cell immune response to various environmental allergens. Inflammation associated airway remodeling in lung diseases mainly represents structural changes associated with a reduction in lung functions, which includes sub-epithelial fibrosis, airway smooth muscle hypertrophy, hyperplasia, tissue eosinophilia, and epithelial injuries [11, 12, 15, 27-31]. These inflammatory responses are usually suppressed by Tregs, which maintain airway immunotolerance through IL-10, which is a vital immunosuppressive and antifibrotic cytokines secreted by the majority of regulatory cells [32-36]. During an immune response, Th1 cells produce IL-2 and IFN- $\gamma$; they are important in immune responses in allergic inflammation while Th2 cells are essential in allergic inflammation through IL-4, IL-5, IL-9, and IL-13 cytokines $[1,37-39]$. Th1 cells secreted IFN- $\gamma$ has inhibitory effects on Th2 cells, and during allergic inflammation, it suppresses isotype switching of IgE and it can also stimulate cell-mediated cytotoxic effects [1]. Furthermore, Th17 cells are a distinct lineage of Th cells expressing IL-17 and mediate neutrophilic type inflammation and exacerbate Th2 mediated-allergic inflammation [40, 41].

Clinical manifestations of asthma are characterized by airway inflammation, airway obstruction, airway hyperresponsiveness, and massive infiltration of eosinophils, neutrophils, T lymphocytes, and mast cells in the airway, which play a crucial role in the initiation and progression of chronic airway inflammation and airway remodeling $[10,12,32,39,42-44]$. The development and prevailing of asthma pathogenesis are highly modulated by both the inflammation of airways and mucosal injury inflicted by chronic inflammation. The activation of mast cells and eosinophils, and the subsequent release of leukotrienes (LTB4, LTE4, LTD4), cationic proteins (histamine), serine proteases, chemical inflammatory mediators, and cytokines make them crucial to lead the epithelium injuries $[45,46]$. This results in the activation and release of fibrogenic cytokines (TGF- $\beta 1$ ) to initiate the process of myofibroblast proliferation, which leads to the progression of subepithelial fibrosis, angiogenesis, smooth muscle hyperplasia, and mucus gland hypertrophy [47-49].

\section{Airway microvascular remodelling}

Clinical studies have shown the role of Tregs in human asthma, but these studies have been hampered by the lack of a clear correlation between Tregs and airway microvascular remodeling, which is the main pathological symptoms of asthma [50, 51]. In healthy lungs, the airway microvasculature supplies key vital functions necessary for maintaining a normal physiological process [52]. In particular, it delivers oxygen and nutrients, and act as a primary site for most of the humoral immune response to foreign antigens, which confers the first line of immunity before the onset of disease. Microvascular remodeling during airway inflammation mainly triggers though the pro-angiogenic action of growth factors and inflammatory mediators, and as seen in both human asthma and allergic reaction that airway microvasculature affected during the progression of the disease, which further signifies the key involvement of microvasculature and airway remodeling during asthma [29, 53-55]. Previous investigations on airway microvascular remodeling in chronic airway inflammation demonstrated that microvascular components of airway remodeling are the vital contributors to the alteration of the airway wall in asthma and COPD (Chronic obstructive pulmonary disease) progression $[43,56]$. Airway microvascular alterations as seen in patients with asthma are accompanied by a rise in airway blood flow and diminished $\beta 2$-adrenergic vasodilator responsiveness, suggesting the presence of endothelial dysfunction, increased microvascular permeability and edema are common features during vascular remodeling in bronchial asthma [54, 57-59]. While most studies identify the immunosuppressive properties of $\mathrm{FOXP3}^{+}$Tregs to control allergic airway inflammation, these studies do not explain any impact of Tregs in microvascular changes and associated remodeling, as reported in clinical conditions [60]. Increased microvascular permeability and edema are common features during vascular remodeling in bronchial asthma [57], however, most previous investigations on airway microvascular remodeling in chronic airway inflammation extracted clinical outcomes of patients with asthma, and these data demonstrated that microvascular components of airway remodeling are vital contributors to the alteration of the airway wall in asthma progression [15, $43,54]$. Interestingly, these airway microvascular perturbations are also seen during the development of COPDs [56]. Most of the ongoing therapies target the suppression of inflammatory response without modulating the actual pathogenic mechanism. Although glucocorticoids are the first drug choice to subdue airway inflammation, glucocorticoid treatment is also associated with the expression of IL-10, FOXP3 (Forkhead box P3) mRNA, and induction of Tregs in bronchoalveolar lavage (BAL) 
of asthmatic patients [61-63]. These observations speculated that the presence of Tregs in BAL is crucial to play an immunoregulatory role in mediating the suppressive effect of corticosteroids [64-67]. In the last decade, several therapeutic alternatives for asthma cure have been acquired; however, their selectivity limits their success because asthma pathology is a multifactorial event. Altogether, these airway microvascular changes in asthma and COPD are strongly associated with airway inflammation and contribute to an increase in airway wall thickness, which is associated with disease progression [54].

\section{Regulatory T cells}

Various $\mathrm{T}$ cells have the potential to mediate targeted immunosuppression, but FOXP3 ${ }^{+}$Treg has emerged as a dominant cell type; they are involved in maintaining tolerance during asthma inflammation [68]. Tregs are potent immunosuppressive cells that are key in maintaining the homeostatic balance during dysregulated immune responses, which is a critical feature of asthma inflammation [69-74]. Tregs are generated in the thymus as a functionally mature $\mathrm{T}$ cell subset and in the periphery of naive $T$ cells and are crucial in maintaining immunological unresponsiveness to self-antigens, and suppressing heightened immune responses destructive to the tissue during asthma inflammation [12, 69, 75-83]. Tregs play a vital role in modulating and regulating immune responses by establishing the phase of immunotolerance and negating toxic inflammatory reactions, which are essential to maintain routine tissue repair as seen in several preclinical and clinical studies $[60,62,84]$. Tregs $\left(\mathrm{CD}^{+} / \mathrm{CD}^{+}\right)$are characterized by intracellular expression of FOXP3, and mainly secrete various key regulatory cytokine, which includes IL-10, TGF- $\beta$ to suppress heightened immune responses, and trigger inducible Treg expansion [85]. FOXP3 ${ }^{+}$natural Tregs and peripheral induced Tregs are key in maintaining immunotolerance against mucosal injury, pathogenic alloimmunity, diabetes, and facilitate tolerance induction in murine models of organ transplantations [77, 81, 86-88].

Treg regulates immune responses through the release of key regulatory cytokines, IL-10, and TGF- $\beta$ and modulates inflammation $[68,89]$. Treg-mediated immunosuppression mainly operates through the secretion of suppressive soluble factors (IL-10, TGF- $\beta$, IL-35, Fibrinogen-like protein 2, CD39, and CD73), cell contact-mediated suppression (through Galactin-1, CTLA-4, LAG-3), and competition for growth factors (e.g. IL-2) [90]. The clinical demand for Treg cell-based immunotherapy is rapidly rising, and different Treg subsets including natural Tregs, induced Tregs, $\mathrm{CD} 8^{+}$Treg cells, and regulatory cells has been reported in various preclinical and clinical studies of asthma, which highlighted a crucial link of airway inflammation, airway remodeling and associated immunosuppressive roles of regulatory $\mathrm{T}$ cells to counter the ongoing cellular and tissue dysfunctions [86, 91, 92].

Immunoregulatory therapies that balance from Th2 to Th1 paradigm have also been investigated but with limited success in clinical trials [93], and in numerous mouse models to investigate the immunological mechanism of asthma pathogenesis $[94,95]$, which further highlighted a modulatory role of regulatory cell mechanism to negate the inflammatory effects of most of the inflammatory cells [12]. Furthermore, several research investigations highlighted the cellular and molecular basis of Treg development and functions and implicate Treg dysregulation in major pulmonary diseases, including asthma [96]. The role of Tregs in asthma is scanty, and quite a few studies have reported their clinical benefits, which show that depletion of FOXP3 ${ }^{+}$Tregs augments, whereas the reconstitution of Tregs subdues lung allergic responses and in some studies of airway hyperresponsiveness (AHR) [97-99]. Alternatively, Treg depletion before sensitization is proven sufficient to augments the severity of inflammation, and AHR in the lung [100]. Adoptive transfer of Tregs has been proven sufficient to subdue inflammation before the start of tissue inflammation and microvascular repair $[77,79]$. These studies emphasized that the reconstitution of antigen-specific FOXP3 ${ }^{+}$Tregs was found to subdue allergic inflammatory responses and hyper reactivity via the IL-10 dependent pathway [33, $81,101]$, and further downregulated established inflammation and prevent airway remodeling when injected after disease onset [102]. The therapeutic application of Tregs has been tested in clinical and preclinical platforms to achieve desired immunosuppression and to suppress asthma inflammation [89, 102-107].

\section{Immunosuppression}

Tregs have been reported in suppressing Th2 mediated immune responses to allergens and subdue allergic inflammatory conditions, and numerous preclinical studies have shown that the adoptive transfer of antigen-specific Tregs subdues the onset and progression of asthma in mice $[84,99,101,108]$. Generally, Tregs prevent the generation of immune responses to self-antigens and other foreign antigens, including allergens, also limit immune responses to pathogens, protecting tissue from severe injuries [81]. Tregs modulate Th2-mediated lung inflammation, and their therapeutic potential is best described by evidence that therapies with Treg in allergic and asthma disease are associated with the induction or restoration of Treg function, e.g. glucocorticoids, allergen immunotherapy [63]. Tregs mediated immunosuppression has the potential to protect against allergic inflammation and asthma pathogenesis [92, 108, 109]. 
The primary immunosuppressive and regulatory function of Tregs is to control immune responsiveness and regulate hyper-airway response [92, 110]. Tregs are involved in maintaining immunological unresponsiveness to selfantigens, inhibit alloimmune inflammatory responses [79], counteract self-reactivity, neutralizing killer T cells during an inflammatory phase [111], and more specifically contribute to suppressing worsened immune reactions, which is destructive to the airway epithelium and normal physiological outcomes.

Treg operates through various immunosuppressive functions that regulate $\mathrm{T}$ lymphocyte, antigen-presenting cell, and innate cell functions through cell-contact, competition for essential growth factors, cytotoxicity $[92,96]$. During allergic inflammation, Tregs mediate immunosuppression through the release of inhibitory cytokine IL-10, TGF- $\beta$, or by cell surface molecules $[110,112]$. IL-10 mainly suppresses the effects of pro-inflammatory cytokines, restores epithelial layer integrity, tissue healing, and inhibits the survival and migration of eosinophils during allergic inflammation. IL-10 also down-regulates IL-4 induced isotype switching of activated B-cells [36, 108, 113]. Besides, Tregs have been associated with the maintenance of immune responses, and secreted immunosuppressive cytokines such as TGF- $\beta$, IL-10, and IL-35 are involved in immune responses following antigens/allergen exposure [114, 115] (Fig. 1).

In addition to the cytokine-mediated suppressive activity, Tregs are also mediate suppressive functions through the release of perforin and granzymes $\mathrm{B}$ and the release of cyclic adenosine monophosphate (cAMP) [90]. However, some clinical studies also validated these roles when treatment with glucocorticosteroids in asthmatics might increase this FOXP3 protein expression within Tregs in humans, and revealed the suppression of Tregs number as reported from lung tissue in a model of asthma [63] while asthmatic patients have been reported to show decreased FOXP3 protein expression within their $\mathrm{CD} 44^{+} \mathrm{CD} 25^{\text {high }} \mathrm{T}$ regulatory cells repertoire [116]. Data collected from patients with asthma further highlighted the crucial role of Treg, which reported lower Tregs ratio and FOXP3 mRNA expression, and lower levels in peripheral blood mononuclear cells may be associated with asthma pathogenesis in humans [117]. A significant number of murine models of allergic inflammation/asthma have been adopted, although none replicates all pathological parameters of human asthma conditions $[94,118]$.

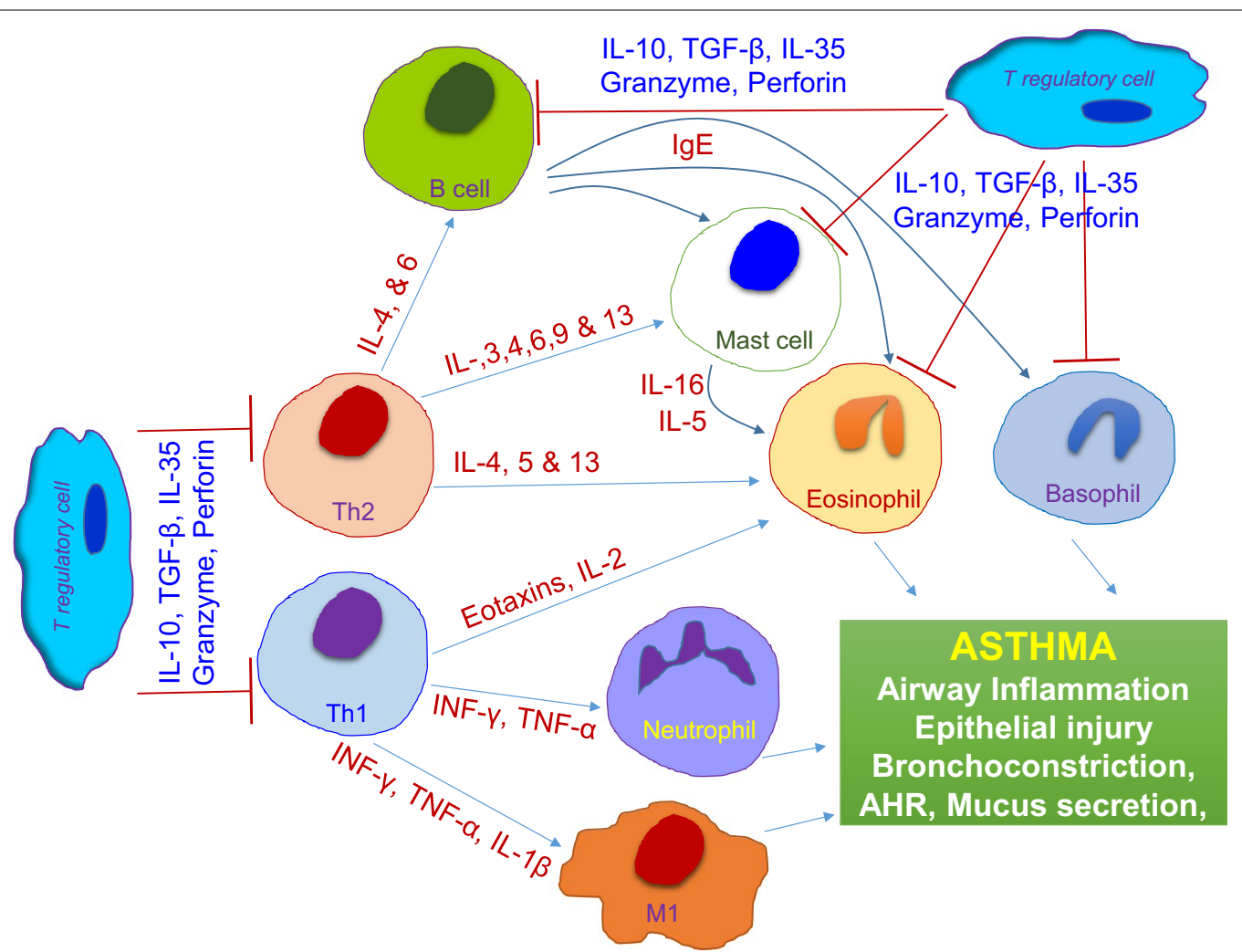

Fig. 1 Overview of the immune system activation during asthma inflammation. Activation of Th1, Th2, B cells, Mast cells, Eosinophils, Neutrophils, Macrophages to promote inflammation, and associated tissue injuries, while Regulatory T cell mediated immunosuppression to check the ongoing inflammatory response 
However, studies in animal models of allergic airway inflammation have investigated a fair amount of preclinical and clinical research, which included the key roles of FOXP3 ${ }^{+}$Treg, IL-10, and TGF- $\beta$ in asthma prevention [108]. In other clinical studies, adoptive transfer of purified antigen-specific $\mathrm{FOXP}^{+}$Treg cells in pre-sensitized mice suppressed AHR, eosinophil recruitment, and Th2 cytokine release through the release of IL-10 and TGF- $\beta$, while the depletion of CD25 ${ }^{+}$Tregs before an allergen challenge shifted Th2 cytokine upregulation, IgE levels, eosinophilia, and AHR in allergy-resistant mice (C3H strain), concluded that Treg control disease resolution [99, 100, 119]. Altogether these previous investigations proved the therapeutic value of Treg to resolve established allergen-induced pulmonary inflammation (eosinophilia, Th2 infiltration, IL-5, IL-13, and TGF- $\beta$, but also prevent the progression of airway remodeling, and reduce mucus hypersecretion and peribronchial collagen deposition [99, 100]. Treg secreted IL-10 is a key antiinflammatory and immunoregulatory cytokine that has distinct pleiotropic effects on both innate and adaptive immunity [120]. Primarily, it restrains inflammation and immune response and extensively participates in immunity activities by regulating cell proliferation, differentiation, and the function of $\mathrm{T}$ cells, $\mathrm{B}$ cells, macrophages, and endothelial cells [108]. IL-10 is produced by FOXP3 ${ }^{+}$Tregs and is also secreted by B cells, natural killer cells, antigen-presenting cells (APCs), mast cells, granulocytes. IL-10 can subdue the release of major pro-inflammatory cytokines such as IFN- $\gamma$, IL-2, IL-3, and TNF- $\alpha$ produced by Th1 cells, activated $\mathrm{T}$ helper cells, mast cells, NK cells, endothelium, eosinophils, and macrophages [33, 108]. Further, IL-10 can modulate Tregs to conserve the intracellular expression of FOXP3 and suppressive functions [121, 122]. IL-10 has wide immunosuppressive and anti-inflammatory properties suitable to attenuate asthma pathology [123, 124]. It is a powerful inhibitor of major proinflammatory cytokines and acts on antigen-presenting cells to subdue $\mathrm{T}$ lymphocyte activation (Th2), suppresses effector cells, mast cells, and eosinophils [33, 108, 114]. In addition, IL-10 augments IgG4 release, which plays a key protective in allergic responses but inhibits IgE [91]. Many clinical studies have reported higher IL-10 in allergic and asthmatics compared to healthy individuals [125]. IL-10 has been involved in effective immunosuppression of allergic immune reactions in the lung [101, 104, 126], which signifies dependence on IL-10 and further highlights the T regulatory cellmediated modulation of pulmonary immune responses. These preclinical reports validated the key role of Tregs during airway remolding and disease progression, and key secreted anti-inflammatory cytokine-IL-10 play a vital role in airway allergic immunomodulation to maintain pulmonary physiological functions, and as reported, IL-10 suppresses Th1- and Th2-type immune responses, inhibits mast cells, eosinophils mediators, and pro-inflammatory cytokines [33, 108, 127]. Also, decreased IL-10 has been observed in allergic and asthmatic diseases compared with healthy control subjects [33]. Collectively, these regulatory networks are crucial to harness the reparative activity of Tregs, which could be an important therapeutic advantage in modulating allergic inflammation [90].

\section{Conclusions}

Tregs mediated immunotherapy is a relatively new addition in modern drug development and therapeutics, and tend to replace conventional immunotherapy without negligible side effects in various inflammation-associated diseases including asthma. Modern drug discovery plan is quickly drifting toward a biological mode of therapeutic agents, which involve cells and their unique products to rescue the disease with minimum side effects, and global research is now in a new era with the introduction of clinical trials investigating the safety and potential therapeutic role of Treg therapy to rescue asthma exacerbations. The multi-regulatory action of Tregs recognized them as a potential candidate to rescue the occurrence of progressive inflammatory modulations, and superiority over the current immunosuppressive regimen, which makes this approach more of therapeutic value and will significantly minimize the cost of current immunosuppression for future medicine. These facts inspire the need for more specific therapies with the potential to support long-term recovery without side effects, and immunotherapeutic based on the understanding of Treg response to the pathophysiology of asthma could have overwhelming benefits for the cure of patients with asthma. In this review, we discussed airway inflammation, remodeling and Treg mediated protection to the progression of asthma pathogenesis. Therefore, the therapeutic use of Tregs to target effector responses may be the key approach to modulate the underlying cause of asthma disease, and to harness the immunoregulatory potency is of utmost requirement in asthma.

\section{Abbreviations}

AHR: Airway hyperresponsiveness; APC: Antigen-presenting cells; BAL:

Bronchoalveolar lavage; CTLA4: Cytotoxic T-lymphocyte-associated protein 4; CAMP: Cyclic adenosine monophosphate; COPD: Chronic obstructive pulmonary diseases; FOXP3: Forkhead box P3; LAG-3: Lymphocyte-activation gene 3; LTB4/ LTE4/ LTD4: Leukotriene B4/E4 and D4; Tregs: Regulatory T cells. 


\section{Acknowledgements}

The author thanks all research staff of the organ transplant research center at King Faisal Special Hospital and Research Centre.

\section{Authors' contributions}

MAK has been involved in writing, compiling the manuscript, and revising it critically for publication standards. The author read and approved the final manuscript.

\section{Funding}

Not available.

\section{Availability of data and materials}

Not applicable.

\section{Ethics approval and consent to participate}

Not applicable.

\section{Consent for publication}

As per journal rules, I disclose that the work has not been published or submitted for publication elsewhere, either completely or in part, or another form or language.

\section{Competing interests}

The author declares that they have no competing interests.

Received: 14 July 2020 Accepted: 26 August 2020

Published online: 02 December 2020

\section{References}

1. Biedermann T, Röcken M, Carballido JM. TH1 and TH2 Lymphocyte development and regulation of TH Cell-mediated immune responses of the skin. J Investig Dermatol Symp Proc. 2004:9:5-14.

2. Alotaibi G. Asthma control and self-management: the role of asthma education. Saudi J Health Sci. 2015;4:16-22.

3. Alreshidi NM. Dimensions of asthma and its treatment in the Kingdom of Saudi Arabia: literature review. Adv Res Gastroenterol Hepatol. 2017:5:01-7.

4. Khan MA, Nicolls MR. Complement-mediated microvascular injury leads to chronic rejection. Adv Exp Med Biol. 2013:734:233-46.

5. Janeway CA Jr, Medzhitov R. Innate immune recognition. Annu Rev Immunol. 2002;20:197-216.

6. Heiss G, Hofmann KW, Trachtmann N, Walters DM, Rouviere P, Knackmuss $\mathrm{HJ}$. npd gene functions of Rhodococcus (opacus) erythropolis $\mathrm{HL}$ PM-1 in the initial steps of 2,4,6-trinitrophenol degradation. Microbiology. 2002;148:799-806.

7. Kew RR, Ghebrehiwet B, Janoff A. Characterization of the third component of complement (C3) after activation by cigarette smoke. Clin Immunol Immunopathol. 1987:44:248-58.

8. Disease GBD, Injury I, Prevalence C. Global, regional, and national incidence, prevalence, and years lived with disability for 328 diseases and injuries for 195 countries, 1990-2016: a systematic analysis for the Global Burden of Disease Study 2016. Lancet. 2017:390:1211-59.

9. Fixman ED, Stewart A, Martin JG. Basic mechanisms of development of airway structural changes in asthma. Eur Respir J. 2007:29:379-89.

10. Khan MA, Assiri AM, Broering DC. Complement mediators: key regulators of airway tissue remodeling in asthma. J Transl Med. 2015;13:272.

11. Khan MA, Nicolls MR, Surguladze B, Saadoun I. Complement components as potential therapeutic targets for asthma treatment. Respir Med. 2014;108:543-9.

12. Khan MA. Inflammation signals airway smooth muscle cell proliferation in asthma pathogenesis. Multidiscip Respir Med. 2013;8:11.

13. Holgate ST, Davies DE, Puddicombe S, Richter A, Lackie P, Lordan J, Howarth P. Mechanisms of airway epithelial damage: epithelial-mesenchymal interactions in the pathogenesis of asthma. Eur Respir J Suppl. 2003:44:24s-9s

14. Hough KP, Curtiss ML, Blain TJ, Liu RM, Trevor J, Deshane JS, Thannickal VJ. Airway remodeling in asthma. Front Med (Lausanne). 2020;7:191.
15. Bergeron C, Tulic MK, Hamid Q. Airway remodelling in asthma: from benchside to clinical practice. Can Respir J. 2010;17:e85-93.

16. Hough KP, Curtiss ML, Blain TJ, Liu R-M, Trevor J, Deshane JS, Thannickal VJ. Airway remodeling in asthma. Front Med. 2020;7:1-18.

17. Bos IS, Gosens R, Zuidhof AB, Schaafsma D, Halayko AJ, Meurs H, Zaagsma J. Inhibition of allergen-induced airway remodelling by tiotropium and budesonide: a comparison. Eur Respir J. 2007;30:653-61.

18. Kohan M, Bader R, Puxeddu I, Levi-Schaffer F, Breuer R, Berkman N. Enhanced osteopontin expression in a murine model of allergeninduced airway remodelling. Clin Exp Allergy. 2007;37:1444-54.

19. Komai M, Tanaka H, Masuda T, Nagao K, Ishizaki M, Sawada M, Nagai H. Role of Th2 responses in the development of allergen-induced airway remodelling in a murine model of allergic asthma. $\mathrm{Br} J$ Pharmacol. 2003:138:912-20.

20. Lloyd CM, Robinson DS. Allergen-induced airway remodelling. Eur Respir J. 2007:29:1020-32.

21. Kupczyk M, Dahlen B, Dahlen SE. Which anti-inflammatory drug should we use in asthma? Pol Arch Med Wewn. 2011:121:455-9.

22. Allen-Ramey FC, Duong PT, Goodman DC, Sajjan SG, Nelsen LM, Santanello NC, Markson LE. Treatment effectiveness of inhaled corticosteroids and leukotriene modifiers for patients with asthma: an analysis from managed care data. Allergy Asthma Proc. 2003;24:43-51.

23. Foresi A, Paggiaro P. Inhaled corticosteroids and leukotriene modifiers in the acute treatment of asthma exacerbations. Curr Opin Pulm Med. 2003:9:52-6.

24. Gex G, Nendaz M, Janssens JP. Leukotriene-modifiers in asthma treatment. Rev Med Suisse. 2006:2:1997-1998-2000-1991.

25. Bagnasco D, Caminati M, Ferrando M, Aloe T, Testino E, Canonica GW, Passalacqua G. Anti-IL-5 and IL-5Ra: efficacy and safety of new therapeutic strategies in severe uncontrolled asthma. Biomed Res Int. 2018:2018:5698212

26. Dahl R. Systemic side effects of inhaled corticosteroids in patients with asthma. Respir Med. 2006;100:1307-17.

27. Khan MA, Ellis R, Inman MD, Bates JH, Sanderson MJ, Janssen LJ. Influence of airway wall stiffness and parenchymal tethering on the dynamics of bronchoconstriction. Am J Physiol Lung Cell Mol Physiol. 2010;299:L98-108.

28. Khan MA, Kianpour S, Stampfli MR, Janssen LJ. Kinetics of in vitro bronchoconstriction in an elastolytic mouse model of emphysema. Eur Respir J. 2007;30:691-700.

29. Khan MA. Dynamics of airway response in lung microsections: a tool for studying airway-extra cellular matrix interactions. J Biomed Sci. 2016a;23:1-8.

30. Khan MA, Alanazi F, Ahmed HA, Shamma T, Kelly K, Hammad MA, Alawad AO, Assiri AM, Broering DC. iPSC-derived MSC therapy induces immune tolerance and supports long-term graft survival in mouse orthotopic tracheal transplants. Stem Cell Res Therapy. 2019;10:290.

31. Khan MA, Shamma T, Kazmi S, Altuhami A, Ahmed HA, Assiri AM, Broering DC. Hypoxia-induced complement dysregulation is associated with microvascular impairments in mouse tracheal transplants. J Transl Med. 2020;18:147.

32. Bousquet J, Jeffery PK, Busse WW, Johnson M, Vignola AM. Asthma. From bronchoconstriction to airways inflammation and remodeling. Am J Respir Crit Care Med. 2000;161:1720-45.

33. Hawrylowicz CM. Regulatory T cells and IL-10 in allergic inflammation. J Exp Med. 2005;202:1459-63.

34. Chaudhry A, Samstein RM, Treuting P, Liang Y, Pils MC, Heinrich JM, Jack RS, Wunderlich FT, Bruning JC, Muller W, Rudensky AY. Interleukin-10 signaling in regulatory $T$ cells is required for suppression of Th17 cellmediated inflammation. Immunity. 2011;34:566-78.

35. Steen EH, Wang X, Balaji S, Butte MJ, Bollyky PL, Keswani SG. The role of the anti-inflammatory cytokine interleukin-10 in tissue fibrosis. Adv Wound Care (New Rochelle). 2020;9:184-98.

36. Sziksz E, Pap D, Lippai R, Beres NJ, Fekete A, Szabo AJ, Vannay A. Fibrosis related inflammatory mediators: role of the IL-10 cytokine family. Mediators Inflamm. 2015;2015:764641.

37. Durrant DM, Metzger DW. Emerging roles of Thelper subsets in the pathogenesis of asthma. Immunol Invest. 2010;39:526-49.

38. Tulic MK, Christodoulopoulos P, Hamid Q. Small airway inflammation in asthma. Respir Res. 2001:2:333-9. 
39. Kaiko GE, Horvat JC, Beagley KW, Hansbro PM. Immunological decisionmaking: how does the immune system decide to mount a helper T-cell response? Immunology. 2008;123:326-38.

40. Jin W, Dong C. IL-17 cytokines in immunity and inflammation. Emerg Microbes Infect. 2013;2:e60.

41. McKinley L, Alcorn JF, Peterson A, DuPont RB, Kapadia S, Logar A, Henry A, Irvin CG, Piganelli JD, Ray A, Kolls JK. T(H) 17 cells mediate steroidresistant airway inflammation and airway hyperresponsiveness in mice. J Immunol (Baltimore, Md: 1950). 2008;181:4089-97.

42. Boulet LP, Turcotte H, Laviolette M, Naud F, Bernier MC, Martel S, Chakir J. Airway hyperresponsiveness, inflammation, and subepithelial collagen deposition in recently diagnosed versus long-standing mild asthma. Influence of inhaled corticosteroids. Am J Respir Crit Care Med. 2000;162:1308-13.

43. Shifren A, Witt C, Christie C, Castro M. Mechanisms of remodeling in asthmatic airways. J Allergy. 2012;2012:1-12.

44. An SS, Bai TR, Bates JH, Black JL, Brown RH, Brusasco V, Chitano P, Deng L, Dowell M, Eidelman DH, et al. Airway smooth muscle dynamics: a common pathway of airway obstruction in asthma. Eur Respir J. 2007;29:834-60.

45. Matsuba S, Yabe-Wada T, Takeda K, Sato T, Suyama M, Takai T, Kikuchi T, Nukiwa T, Nakamura A. Identification of secretory leukoprotease inhibitor as an endogenous negative regulator in allergic effector cells. Front Immunol. 2017:8:1538-1538.

46. Metcalfe DD, Pawankar R, Ackerman SJ, Akin C, Clayton F, Falcone FH, Gleich GJ, Irani AM, Johansson MW, Klion AD, et al. Biomarkers of the involvement of mast cells, basophils and eosinophils in asthma and allergic diseases. World Allergy Organ J. 2016;9:7.

47. Duvernelle C, Freund V, Frossard N. Transforming growth factor-beta and its role in asthma. Pulm Pharmacol Ther. 2003;16:181-96.

48. Halwani R, Al-Muhsen S, Al-Jahdali H, Hamid Q. Role of transforming growth factor-beta in airway remodeling in asthma. Am J Respir Cell Mol Biol. 2011;44:127-33.

49. Nomura A, Uchida Y, Sakamoto T, Ishii Y, Masuyama K, Morishima Y, Hirano K, Sekizawa K. Increases in collagen type I synthesis in asthma: the role of eosinophils and transforming growth factor-beta. Clin Exp Allergy. 2002;32:860-5.

50. Chen T, Hou X, Ni Y, Du W, Han H, Yu Y, Shi G. The imbalance of FOXP3/ GATA3 in regulatory $T$ cells from the peripheral blood of asthmatic patients. J Immunol Res. 2018;2018:3096183.

51. Hamzaoui A, Ammar J, Hamzaoui K. Regulatory T cells in induced sputum of asthmatic children: association with inflammatory cytokines. Multidiscip Respir Med. 2010;5:22-30.

52. Jacob M, Chappell D, Becker BF. Regulation of blood flow and volume exchange across the microcirculation. Crit Care. 2016;20:319.

53. Siafakas NM, Antoniou KM, Tzortzaki EG. Role of angiogenesis and vascular remodeling in chronic obstructive pulmonary disease. Int J Chron Obstr Pulm Dis. 2007;2:453-62.

54. Zanini A, Chetta A, Imperatori AS, Spanevello A, Olivieri D. The role of the bronchial microvasculature in the airway remodelling in asthma and COPD. Respir Res. 2010;11:132-132.

55. Persson C. Airways exudation of plasma macromolecules: innate defense, epithelial regeneration, and asthma. J Allergy Clin Immunol. 2019;143:1271-86.

56. Voelkel NF, Gomez-Arroyo J, Mizuno S. COPD/emphysema: the vascular story. Pulm Circ. 2011;1:320-6.

57. Orihara K, Matsuda A. Pathophysiological roles of microvascular alterations in pulmonary inflammatory diseases: possible implications of tumor necrosis factor-alpha and CXC chemokines. Int J Chronic Obstr Pulm Dis. 2008;3:619-27.

58. Green CE, Turner AM. The role of the endothelium in asthma and chronic obstructive pulmonary disease (COPD). Respir Res. 2017;18:20.

59. Wanner A, Mendes ES. Airway endothelial dysfunction in asthma and chronic obstructive pulmonary disease: a challenge for future research. Am J Respir Crit Care Med. 2010;182:1344-51.

60. Eusebio M, Kuna P, Kraszula L, Kupczyk M, Pietruczuk M. The relative values of CD8+CD25+Foxp3brigh Treg cells correlate with selected lung function parameters in asthma. Int $\mathrm{J}$ Immunopathol Pharmacol. 2015;28:218-26

61. Peek EJ, Richards DF, Faith A, Lavender P, Lee TH, Corrigan CJ, Hawrylowicz CM. Interleukin-10-secreting "regulatory" $T$ cells induced by glucocorticoids and beta2-agonists. Am J Respir Cell Mol Biol. 2005;33:105-11.

62. Hartl D, Koller B, Mehlhorn AT, Reinhardt D, Nicolai T, Schendel DJ, Griese M, Krauss-Etschmann S. Quantitative and functional impairment of pulmonary CD4+CD25hi regulatory T cells in pediatric asthma. J Allergy Clin Immunol. 2007;119:1258-66.

63. Karagiannidis C, Akdis M, Holopainen P, Woolley NJ, Hense G, Ruckert B, Mantel PY, Menz G, Akdis CA, Blaser K, Schmidt-Weber CB. Glucocorticoids upregulate FOXP3 expression and regulatory T cells in asthma. J Allergy Clin Immunol. 2004;1 14:1425-33.

64. Neujahr DC, Cardona AC, Ulukpo O, Rigby M, Pelaez A, Ramirez A, Gal AA, Force SD, Lawrence EC, Kirk AD, Larsen CP. Dynamics of human regulatory $T$ cells in lung lavages of lung transplant recipients. Transplantation. 2009:88:521-7.

65. Maneechotesuwan K, Kasetsinsombat K, Wamanuttajinda V, Wongkajornsilp A, Barnes PJ. Statins enhance the effects of corticosteroids on the balance between regulatory T cells and Th17 cells. Clin Exp Allergy. 2013:43:212-22.

66. Sbiera S, Dexneit T, Reichardt SD, Michel KD, van den Brandt J, Schmull S, Kraus L, Beyer M, Mlynski R, Wortmann S, et al. Influence of shortterm glucocorticoid therapy on regulatory T cells in vivo. PLoS ONE. 2011;6:e24345.

67. Faustino L, Mucida D, Keller AC, Demengeot J, Bortoluci K, Sardinha LR, Carla Takenaka M, Basso AS, Faria AMC, Russo M. Regulatory T cells accumulate in the lung allergic inflammation and efficiently suppress T-cell proliferation but not Th2 cytokine production. Clin Dev Immunol. 2012;2012:13

68. Zhang $H$, Kong $H$, Zeng $X$, Guo L, Sun $X$, He S. Subsets of regulatory $T$ cells and their roles in allergy. J Transl Med. 2014;12:125.

69. Fehervari Z, Sakaguchi S. CD4+ Tregs and immune control. J Clin Invest. 2004;114:1209-17.

70. Onishi H, Morisaki T, Katano M. Immunotherapy approaches targeting regulatory T-cells. Anticancer Res. 2012;32:997-1003.

71. Pellerin L, Jenks JA, Bégin P, Bacchetta R, Nadeau KC. Regulatory T cells and their roles in immune dysregulation and allergy. Immunol Res. 2014:58:358-68.

72. Sakaguchi S, Yamaguchi T, Nomura T, Ono M. Regulatory T cells and immune tolerance. Cell. 2008;133:775-87.

73. Schmidt A, Oberle N, Krammer PH. Molecular mechanisms of tregmediated T cell suppression. Front Immunol. 2012;3:51.

74. Singer BD, King LS, D'Alessio FR. Regulatory T cells as immunotherapy. Front Immunol. 2014;5:46

75. Cobbold SP, Graca L, Lin CY, Adams E, Waldmann H. Regulatory T cells in the induction and maintenance of peripheral transplantation tolerance. Transpl Int. 2003;16:66-75.

76. Khan MA. T regulatory cell mediated immunotherapy for solid organ transplantation: a clinical perspective. Mol Med. 2016b;22:892-904.

77. Khan MA, Alanazi F, Ahmed HA, Al-Mohanna FH, Assiri AM, Broering DC. FOXP3 + regulatory T cell ameliorates microvasculature in the rejection of mouse orthotopic tracheal transplants. Clin Immunol. 2017;174:84-98.

78. Khan MA, Alanazi F, Ahmed HA, Vater A, Assiri AM, Broering DC. C5a blockade increases regulatory $T$ cell numbers and protects against microvascular loss and epithelial damage in mouse airway allografts. Front Immunol. 2018:9:1010.

79. Khan MA, Moeez S, Akhtar S. T-regulatory cell-mediated immune tolerance as a potential immunotherapeutic strategy to facilitate graft survival. Blood Transfus. 2013;11:357-63.

80. Khan MA, Shamma T. Complement factor and T-cell interactions during alloimmune inflammation in transplantation. J Leukoc Biol. 2018;104:681-94.

81. Lloyd CM, Hawrylowicz CM. Regulatory T cells in asthma. Immunity. 2009:31:438-49.

82. Bilate AM, Lafaille JJ. Induced CD4+Foxp3+ regulatory T cells in immune tolerance. Annu Rev Immunol. 2012;30:733-58.

83. Josefowicz SZ, Lu LF, Rudensky AY. Regulatory T cells: mechanisms of differentiation and function. Annu Rev Immunol. 2012;30:531-64.

84. Schreiber TH, Wolf D, Tsai MS, Chirinos J, Deyev W, Gonzalez L, Malek TR, Levy RB, Podack ER. Therapeutic Treg expansion in mice by TNFRSF25 prevents allergic lung inflammation. J Clin Invest. 2010;120:3629-40. 
85. Sakaguchi S. Naturally arising Foxp3-expressing CD25+CD4+ regulatory T cells in immunological tolerance to self and non-self. Nat Immunol. 2005;6:345-52.

86. Marek-Trzonkowska N, Mysliwiec M, Dobyszuk A, Grabowska M, Techmanska I, Juscinska J, Wujtewicz MA, Witkowski P, Mlynarski W, Balcerska A, et al. Administration of CD4+CD25highCD127-regulatory T cells preserves beta-cell function in type 1 diabetes in children. Diabetes Care. 2012;35:1817-20.

87. Lundgren A, Stromberg E, Sjoling A, Lindholm C, Enarsson K, Edebo A, Johnsson E, Suri-Payer E, Larsson P, Rudin A, et al. Mucosal FOXP3-expressing CD4+ CD25high regulatory $T$ cells in Helicobacter pylori-infected patients. Infect Immun. 2005;73:523-31.

88. Heim C, Khan MA, von Silva-Tarouca B, Kuckhahn A, Stamminger T, Ramsperger-Gleixner M, Nicolls MR, Weyand M, Ensminger SM. Preservation of microvascular integrity in murine orthotopic tracheal allografts by clopidogrel. Transplantation. 2019;103:899-908.

89. Matsuda M, Terada T, Kitatani K, Kawata R, Nabe T. Analyses of Foxp3(+)Treg cells and $\operatorname{Tr} 1$ cells in subcutaneous immunotherapy-treated allergic individuals in humans and mice. Nihon Yakurigaku Zasshi. 2019;154:17-22.

90. Thorburn AN, Hansbro PM. Harnessing regulatoryT cells to suppress asthma: from potential to therapy. Am J Respir Cell Mol Biol. 2010;43:511-9.

91. Akdis CA, Akdis M. Mechanisms of allergen-specific immunotherapy and immune tolerance to allergens. World Allergy Organ J. 2015;8:17.

92. Palomares O, Yaman G, Azkur AK, Akkoc T, Akdis M, Akdis CA. Role of Treg in immune regulation of allergic diseases. Eur J Immunol. 2010;40:1232-40.

93. Maggi E. T cell responses induced by allergen-specific immunotherapy. Clin Exp Immunol. 2010;161:10-8.

94. Nials AT, Uddin S. Mouse models of allergic asthma: acute and chronic allergen challenge. Dis Models Mech. 2008;1:213-20.

95. Lloyd CM. Building better mouse models of asthma. Current Allergy Asthma Rep. 2007;7:231-6.

96. Larche M. Regulatory T cells in allergy and asthma. Chest. 2007;132:1007-14.

97. Baru AM, Hartl A, Lahl K, Krishnaswamy JK, Fehrenbach H, Yildirim AO, Garn $H$, Renz H, Behrens GM, Sparwasser T. Selective depletion of Foxp3+ Treg during sensitization phase aggravates experimental allergic airway inflammation. Eur J Immunol. 2010;40:2259-66.

98. Baru AM, Ganesh V, Krishnaswamy JK, Hesse C, Untucht C, Glage S, Behrens G, Mayer CT, Puttur F, Sparwasser T. Absence of Foxp3(+) regulatory T cells during allergen provocation does not exacerbate murine allergic airway inflammation. PLoS ONE. 2012;7:e47102.

99. Xu W, Lan Q, Chen M, Chen H, Zhu N, Zhou X, Wang J, Fan H, Yan C-S, Kuang $J$ - $L$, et al. Adoptive transfer of induced-Treg cells effectively attenuates murine airway allergic inflammation. PLOS ONE. 2012;7:e40314.

100. Lewkowich IP, Herman NS, Schleifer KW, Dance MP, Chen BL, Dienger KM, Sproles AA, Shah JS, Kohl J, Belkaid Y, Wills-Karp M. CD4+CD25+T cells protect against experimentally induced asthma and alter pulmonary dendritic cell phenotype and function. J Exp Med. 2005;202:1549-61.

101. Kearley J, Barker JE, Robinson DS, Lloyd CM. Resolution of airway inflammation and hyperreactivity after in vivo transfer of CD4+CD25+ regulatory $T$ cells is interleukin 10 dependent. J Exp Med. 2005;202:1539-47.

102. Kearley J, Robinson DS, Lloyd CM. CD4+CD25+ regulatory T cells reverse established allergic airway inflammation and prevent airway remodeling. J Allergy Clin Immunol. 2008;122(617-624):e616.

103. Joetham A, Takeda K, Okamoto M, Taube C, Matsuda H, Dakhama A, Gelfand EW. Antigen specificity is not required for modulation of lung allergic responses by naturally occurring regulatory $T$ cells. J Immunol. 2009;183:1821-7.

104. Joetham A, Takeda K, Taube C, Miyahara N, Matsubara S, Koya T, Rha YH, Dakhama A, Gelfand EW. Naturally occurring lung CD4(+)CD25(+)T cell regulation of airway allergic responses depends on IL-10 induction of TGFbeta. J Immunol. 2007;178:1433-42.

105. Tortola L, Pawelski H, Sonar SS, Ampenberger F, Kurrer M, Kopf M. IL-21 promotes allergic airway inflammation by driving apoptosis of FoxP3(+) regulatory T cells. J Allergy Clin Immunol. 2019;143(2178-2189):e2175.

106. He YT, Zhou Y, Shao Q, Gan C, Chen M, Bao YL, Gu HY, Zhang SL, Cui Y, Tian M. Immunoregulatory effects of subcutaneous immunotherapy on lymphocyte subgroups and cytokines in children with asthma. J Immunol Res. 2019;2019:7024905.
107. Gorczynski RM, Maqbool T, Hoffmann G. Mechanism(s) of prolonged attenuation of allergic responses after modulation of idiotypic regulatory network. Allergy Asthma Clin Immunol. 2019;15:79.

108. Böhm L, Maxeiner J, Meyer-Martin H, Reuter S, Finotto S, Klein M, Schild H, Schmitt E, Bopp T, Taube C. IL-10 and regulatory T cells cooperate in allergen-specific immunotherapy to ameliorate allergic asthma. J Immunol. 2015;194:887-97.

109. Kohl J, Baelder R, Lewkowich IP, Pandey MK, Hawlisch H, Wang L, Best J, Herman NS, Sproles AA, Zwirner J, et al. A regulatory role for the C5a anaphylatoxin in type 2 immunity in asthma. J Clin Invest. 2006;116:783-96.

110. Verhagen J, Blaser K, Akdis CA, Akdis M. Mechanisms of allergen-specific immunotherapy: T-regulatory cells and more. Immunol Allergy Clin N Am. 2006;26(207-231):vi.

111. Issa F, Wood KJ. CD4+ regulatory T cells in solid organ transplantation. Curr Opin Organ Transplant. 2010;15:757-64.

112. Taylor A, Verhagen J, Blaser K, Akdis M, Akdis CA. Mechanisms of immune suppression by interleukin-10 and transforming growth factor-beta: the role of T regulatory cells. Immunology. 2006;117:433-42.

113. Murdoch JR, Lloyd CM. Chronic inflammation and asthma. Mutat Res. 2010;690:24-39.

114. Chung F. Anti-inflammatory cytokines in asthma and allergy: interleukin-10, interleukin-12, interferon-gamma. Mediators Inflamm. 2001;10:51-9.

115. Chung KF, Barnes PJ. Cytokines in asthma. Thorax. 1999;54:825-57.

116. Provoost S, Maes T, van Durme YM, Gevaert P, Bachert C, Schmidt-Weber CB, Brusselle GG, Joos GF, Tournoy KG. Decreased FOXP3 protein expression in patients with asthma. Allergy. 2009;64:1539-46.

117. Krogulska A, Polakowska E, Wasowska-Krolikowska K, Malachowska B, Mlynarski W, Borowiec M. Decreased FOXP3 mRNA expression in children with atopic asthma and lgE-mediated food allergy. Ann Allergy Asthma Immunol. 2015;115:415-21.

118. Carson WF, Guernsey LA, Singh A, Vella AT, Schramm CM, Thrall RS. Accumulation of regulatory $T$ cells in local draining lymph nodes of the lung correlates with spontaneous resolution of chronic asthma in a murine model. Int Arch Allergy Immunol. 2008;145:231-43.

119. Burchell JT, Wikstrom ME, Stumbles PA, Sly PD, Turner DJ. Attenuation of allergen-induced airway hyperresponsiveness is mediated by airway regulatory T cells. Am J Physiol Lung Cell Mol Physiol. 2009;296:L307-19.

120. Hara M, Kingsley Cl, Niimi M, Read S, Turvey SE, Bushell AR, Morris PJ, Powrie F, Wood KJ. IL-10 is required for regulatory $T$ cells to mediate tolerance to alloantigens in vivo. J Immunol. 2001;166:3789-96.

121. Bharat A, Fields RC, Steward N, Trulock EP, Patterson GA, Mohanakumar T. $\mathrm{CD} 4+25+$ regulatory $T$ cells limit Th1-autoimmunity by inducing IL-10 producing T cells following human lung transplantation. Am J Transplant. 2006;6:1799-808.

122. Hsu P, Santner-Nanan B, Hu M, Skarratt K, Lee CH, Stormon M, Wong M, Fuller SJ, Nanan R. IL-10 potentiates differentiation of human induced regulatory T cells via STAT3 and Foxo1. J Immunol. 2015;195:3665-74.

123. Ng THS, Britton GJ, Hill EV, Verhagen J, Burton BR, Wraith DC. Regulation of adaptive immunity; the role of interleukin-10. Front Immunol. 2013;4:129.

124. O'Garra A, Barrat FJ, Castro AG, Vicari A, Hawrylowicz C. Strategies for use of IL-10 or its antagonists in human disease. Immunol Rev. 2008;223:114-31.

125. Taams LS, Palmer DB, Akbar AN, Robinson DS, Brown Z, Hawrylowicz CM. Regulatory $T$ cells in human disease and their potential for therapeutic manipulation. Immunology. 2006;118:1-9.

126. Leech MD, Benson RA, De Vries A, Fitch PM, Howie SE. Resolution of Der p1-induced allergic airway inflammation is dependent on CD4+CD25+Foxp3+ regulatory cells. J Immunol. 2007;179:7050-8.

127. Lim S, Caramori G, Tomita K, Jazrawi E, Oates T, Chung KF, Barnes PJ, Adcock IM. Differential expression of IL-10 receptor by epithelial cells and alveolar macrophages. Allergy. 2004;59:505-14.

\section{Publisher's Note}

Springer Nature remains neutral with regard to jurisdictional claims in published maps and institutional affiliations. 